\title{
Alternative treatments in bean seeds for repelling Acanthoscelides obtectus (SAY) ${ }^{1}$
}

\author{
Marcelo Ramos de Oliveira ${ }^{2}$, Lisandro Tomas da Silva Bonome ${ }^{2 *}$, Henrique von \\ Hertwig Bittencourt ${ }^{2}$, Edenilson Zarowni ${ }^{2}$, Luan da Silva Lefchak ${ }^{3}$
}

\begin{abstract}
The objectives of this study were to evaluate treatments with alternative products for repelling bean weevils, and to assess their influence on the physiological quality of Phaseolus vulgaris seeds. The experiment was carried out in a completely randomized design, with four replications, in a two-factorial scheme (10x4). It comprised 10 treatments: Piper nigrum, diatomaceous earth and kaolin (4 g/kg of seed); Cinnamomum zeylanicum, Citrus sinensis and Eucalyptus sp. (1\% of the seed weight); Azadirachta indica oil $(3 \mathrm{~mL} / \mathrm{kg}$ of seed); Gastoxin ( $6 \mathrm{~g} / \mathrm{t}$ of seed); PET container; control; and the storage times of $0,25,50$, and 75 days. The variables seed moisture content, germination, emergence speed, mean emergence time, weight of one thousand seeds, seed infestation, and repellency were evaluated. The treatments with kaolin and $A$. indica had a repellent effect at first, but they lost effectiveness by the end of the storage period. The products based on C. zeylanicum and Eucalyptus sp. did not have such impact during early periods of storage, albeit repellency grew with time. On the other hand, $C$. sinensis and diatom-based products were repellents, both at the beginning and at the end of storage. The treatments with diatomaceous earth, kaolin, P. nigrum, C. zeylanicum, Eucalyptus sp., A. indica, and PET container all proved to be effective in reducing bean weevil infestation, without negatively impacting the physiological quality of the seeds.
\end{abstract}

Index terms: seed storage, bean weevil, Phaseolus vulgaris, alternative product, seed quality.

\section{Tratamentos alternativos em sementes de feijão para repelência de Acanthoscelides obtectus (SAY)}

\begin{abstract}
RESUMO - Objetivou-se avaliar os tratamentos com produtos alternativos na repelência do caruncho do feijão e na qualidade fisiológica de sementes de Phaseolus vulgaris. Utilizou-se delineamento experimental inteiramente casualizado, com quatro repetições, em esquema bifatorial (10x4). Os 10 tratamentos foram: Piper nigrum, diatomáceas e caulim (4 g/kg de semente); Cinnamomum zeylanicum, Citrus sinensis e cinza de Eucalyptus sp. ( $1 \%$ do peso de semente); óleo de Azadirachta indica ( $3 \mathrm{~mL} / \mathrm{kg}$ de semente); Gastoxin (6 g/t semente); garrafa pet; testemunha; e quatro períodos de armazenamento $(0,25,50$ e 75 dias). Foram avaliadas as variáveis umidade, germinação, velocidade de emergência, tempo médio de emergência, peso de mil sementes, sementes infestadas e repelência. Os tratamentos com caulim e $A$. indica foram repelentes no início do tratamento, porém perderam a eficácia ao final do armazenamento. Os produtos a base de C. zeylanicum e Eucalyptus sp. não foram repelentes no início do tratamento, porém o foram no final do armazenamento. Já os produtos a base de $C$. sinensis e diatomáceas foram repelentes tanto no início quanto no final do armazenamento. Os tratamentos com diatomáceas, caulim, P. nigrum, C. zeylanicum, Eucalyptus sp., A. indica e a embalagem pet são eficientes em reduzir a infestação do caruncho sem impactar negativamente na qualidade fisiológica das sementes.
\end{abstract}

Termos para indexação: armazenamento de sementes, caruncho-do-feijão, Phaseolus vulgaris, produto alternativo, qualidade de sementes.

\section{Introduction}

The common bean - Phaseolus vulgaris Linnaeus, 1753 - is one of the most important products in Brazil's

\footnotetext{
${ }^{1}$ Submitted on 02/25/2018. Accepted for publication on 07/13/2018. ${ }^{2}$ Departamento de Agronomia, Universidade Federal da Fronteira Sul, 85301-970 - Laranjeiras do Sul, PR, Brasil.
}

agriculture, both economically and socially, once it represents a vital source of energy and protein for a vast amount of the population (Cristo et al., 2014). The country places third in world production of beans (behind Myanmar and India, only),

\footnotetext{
${ }^{3}$ Departamento de Engenharia de Aquicultura, Universidade Federal da Fronteira Sul, 85301-970 - Laranjeiras do Sul, PR, Brasil.

*Corresponding author $<$ lisandrobonome@gmail.com $>$
} 
and the Brazilian state of Paraná is regarded as the leading producer, accounting for $23 \%$ of the national production.

Similarly to grains and seeds of other cultures, beans usually are stored after harvest to further consumption or commercialization. Incorrect storage may cause several problems by lowering the physiological quality of seeds for planting, and grains for consumption. One of the main causes of loss during storage is the occurrence of weevil. In Brazil, the species -Acanthoscelides obtectus Say, 1831 - and Zabrotes subfasciatus Bohemann, 1833 (Coleoptera: Bruchidae) - are particularly important, due to the damages they cause to $P$. vulgaris cultures (Gallo et al., 2002).

The weevil A. obtectus occurs in all Brazilian states that produce beans (Damiani et al., 2014). It is capable of reproducing in temperate and tropical climates, with one or two generations in the field. Besides, its dispersion can range up to an $8-\mathrm{km}$ radius, and it can infest stored grains, and also unripe unharvested pods (Gallo et al., 2002).

Due to its characteristics, A. obtectus is considered the most important bean pest, from an economic perspective. It is a primary pest, which makes a hole on the tegument of the seed and colonizes it to proceed with its development, feeding on the cotyledons while doing so. Therefore, it favors the attack of other insects and microorganisms (Jiménez et al., 2017). Several damages result from the penetration and feeding of the larva, including weight loss, a decrease in the nutritional value and hygiene of the product, contamination by excrements, eggs and insects, and reduction of seed germination (Gallo et al., 2002).

The usual method to control weevil in beans is the fumigation with chemicals, among them aluminum phosphide and magnesium phosphide. Most of the times, in addition to this practice, pyrethroid or phosphate insecticides are applied on the surface of the grains or over the sacks to avoid reinfestation (Oliveira et al., 2013). Despite being efficient, chemical methods for controlling pests of stored goods are highly toxic and pose contamination risk for both man and the environment.

Due to health and environmental problems associated to synthetic chemical compounds used to control weevil in stored seeds and grains, researches have recently focused their efforts on finding alternative substances that have less impact on non-target organisms (Lima-Mendonça et al., 2013; Ootani et al., 2013). Among the studied possibilities, animal and vegetable oils (Mateus et al., 2017; Campos et al., 2014), diatomaceous earth (Lima et al., 2014; Silva et al., 2012), and dry powdered plant products (Melo et al., 2014) have stood out, owing to their potential of use.

In face of the considerable losses caused by A. obtectus in stored bean seeds, and due to the interest in substances with insecticide action that are less harmful to human health and nature, this work aimed to estimate the effect of the treatment with alternative products in repelling A. obtectus, and in the quality of stored seeds of $P$. vulgaris cv. IPR Tuiuiú.

\section{Material and Methods}

The present work was carried out in the Laboratory of Plant Physiology, Germination, and Entomology at the Universidade Federal da Fronteira Sul (UFFS), campus Laranjeiras do Sul, state of Paraná (PR). The seed producer's cooperative of Laranjeiras do Sul (Coprossel) provided the bean seeds, variety IPR Tuiuiú, used in the study.

The experiment followed a completely randomized design, with a bi-factorial scheme $10 \times 4$, and four replications. The levels of the factor A were the following: black pepper-Piper nigrum Linnaeus, 1753 - diatomaceous earth from Bugram Protect ${ }^{\circledR}$, and kaolin (4 g/ kg of seed); cinnamon bark - Cinnamomum zeylanicum Presl, 1825 orange peel - Citrus Linnaeus, 1753 - sinensis Osbeck, 1765 - and eucalyptus ashes (Eucalyptus sp.) (1\% of the seed weight); neem oil from Vitaplant Ltda - Azadirachta indica Jussieu, 1830 - (3 mL/kg of seed); Gastoxin ${ }^{\circledR}$ B57 (6 $\mathrm{g} / \mathrm{t}$ of seed); PET container; and control (untreated seeds). The levels of factor D considered four storage times: 0,25 , 50 , and 75 days.

To obtain powdered products from black pepper, cinnamon bark, and orange peel, they were dehydrated in an oven at $40{ }^{\circ} \mathrm{C}$ for $48 \mathrm{~h}$, and then ground in a knife-blade Wiley mill with a 2-mm sieve. Ashes of Eucalyptus sp. were produced by incinerating it in a wood burning stove, and then passing it through a tulle fabric (1-mm mesh). The plant materials were collected in August 2016, they being cinnamon bark from Marmeleiro (PR), eucalyptus and orange peel from Rio Bonito do Iguaçu (PR), and black pepper from Laranjeiras do Sul (PR).

The seeds were divided into samples of $400 \mathrm{~g}$, and each one of these sets was transferred to a plastic bag where the treatments and homogenization where performed, totalizing 40 units. After the treatment, each replication was packed in a kraft paper bag and stowed in a plastic bucket with a roughly capacity of 20 liters. After three days, each replication was infested with 10 adult insects, unspecified sex, aged approximately four days. The buckets had their opening closed with a proper cloth to prevent the escape of weevils, and the treatments were stored for 75 days in the shade, under conditions of room temperature and uncontrolled relative humidity. For the repellency test, seeds clean of weevil from each treatment were used. 
After every storage time $(0,25,50$, and 75 days), one sample of seeds was taken from each replication and submitted to the following tests: moisture content, germination, emergence speed index (ESI), mean emergence time (MET), seed infestation, and weight of one thousand seeds.

The determination of moisture content was performed as proposed by Rules for Seed Testing (Brasil, 2009), using the oven method at $105 \pm 3{ }^{\circ} \mathrm{C}$ for $24 \mathrm{~h}$, and a 50 -gram sample of seeds from each treatment.

The germination test was carried out in four replications of 50 seeds for each treatment. The seeds were placed to germinate on germitest papers, which had been previously moistened with a proportion of $2.5 \mathrm{~mL}$ of distilled water per gram of paper. The treatments remained inside a Mangelsdorf germination chamber set at $25 \pm 2{ }^{\circ} \mathrm{C}$ for nine days, as recommended by Rules for Seed Testing (Brasil, 2009). Normal seedlings were counted on the fifth and ninth days after sowing. On the ninth day, the total number of normal and abnormal seedlings, as well as that of dead seeds, were determined (Brasil, 2009).

Four replications of 50 seeds each were used for the ESI and MET tests. The seeds were sowed in 128-cell seedling trays, made of polystyrene foam, with dimensions of $(66.3 \times 34.4 \times$ 6.2) $\mathrm{cm}$ and volume of $0.0144 \mathrm{~m}^{3}$. The sand was previously sieved through a 2-mm mesh and sterilized in an autoclave at 120 ${ }^{\circ} \mathrm{C}$ for $15 \mathrm{~min}$. The seeds were planted and covered with $1 \mathrm{~cm}$ of sand. The trays were kept in a greenhouse, with the temperature set at $25 \pm 2{ }^{\circ} \mathrm{C}$ for 15 days, and watered three times a day for 2 min. The irrigations provided a liquid layer of $6 \mathrm{~mm} \cdot \mathrm{dia}^{-1}$ per aspersion system, at intervals of $5 \mathrm{~h}$ during the day.

Every day, from the second day on after sowing, the emergence of seedlings was accounted for calculating the ESI and MET. Emerged seedlings that had reached 2 $\mathrm{cm}$ above substrate level, and which had presented all the essential structures for a normal plant formation, were those considered. The evaluation continued until the number of emerged seedlings stabilized. Then, the ESI and MET were calculated by using the formulas proposed by Maguire (1962) and Lima et al. (2006), respectively.

The assessment of the infested seeds was conducted according to the guidelines of Rules for Seed Testing (Brasil, 2009), using four replications of 50 seeds per treatment. After each replication, the number of seeds perforated by the insects was accounted. Seeds without perforations or visible damages were submerged in water for a period of 12 to $24 \mathrm{~h}$ to soften them. Then, they were individually cut so that the internal structure could be visualized to detect eggs, larvae, pupae, adult insects, as well as any exit holes.

The test to determine the weight of one thousand seeds followed the methodology by Rules for Seed Testing (Brasil, 2009). According to it, eight replications of 100 seeds from each treatment were counted randomly.

The insects A. obtectus were farmed in the entomology laboratory, where they multiplied under a temperature of $25 \pm 2$ ${ }^{\circ} \mathrm{C}$, relative humidity of $60 \% \pm 10 \%$, and a photoperiod of $12 \mathrm{~h}$. They were kept in $2 \mathrm{~L}$ jars containing beans and sealed with a specific cloth.

To perform the repellency test, the treatments were examined individually by using an arena formed by three round plastic containers (acrylic Petri dishes, $10 \mathrm{~cm}$ x $2 \mathrm{~cm}$ ), where the central one was symmetrically connected to the others through a transparent plastic tube $(10 \mathrm{~cm})$, in a longitudinal orientation. An amount of $20 \mathrm{~g}$ of seed was put in each lateral container: one was assumed as the control, and the other as the treatment. In the central container, 25 adult insects were released and, after $24 \mathrm{~h}$, the number of insects in each container was counted. In this test, the bi-factorial scheme 10x2 was used. It considers ten treatments and two periods of evaluations (after the treatment of the seeds and after six months of storage), with four replications for each treatment.

The repellency index (RI) was determined by the Equation 1 .

$$
\mathrm{RI}=2 \mathrm{G} /(\mathrm{G}+\mathrm{P}) \text { [Equation 1] }
$$

Where: $\mathrm{G}=\%$ of insects in the treatment container, and $\mathrm{P}=\%$ of insects in the control container. The RI values ranged between $0-2$, which means as follows: $I R=1$, neutral plant; $I R>1$, attractive plant; and $\mathrm{RI}<1$, repellent plant (Lin et al., 1990).

The data collected were submitted to the normality test, analysis of variance (ANOVA), and F test; means were compared by using the Tukey's test at a 0,05 level of significance. The statistical analyses were performed with the software Assistat (Silva and Azevedo, 2016).

\section{Results and Discussion}

The treatments showed similar behavior, with a reduction in the moisture content of the seeds by approximately 5 percentage points, during the first 50 days of storage, followed by an increase of about $1.5 \%$ by the $75^{\text {th }}$ day (Figure 1). The seeds kept in PET containers were an exception since their moisture content remained constant throughout the entire storage time.

This result was expected, once the seeds were stored in permeable packing (Kraft paper bags), which allows gaseous exchanges with the environment. Therefore, seed moisture content suffers alterations according to the relative humidity in the storage room (Silva et al., 2010). 
The treatments with orange peel, black pepper, and neem oil had an immediate phytotoxic effect on the bean seeds when compared to the control, resulting in reductions of $11.50,20$, and 16.50 percentage points, respectively (Table 1). Nevertheless, the phytotoxicity was minimized along the storage, until the $50^{\text {th }}$ day. By the $75^{\text {th }}$ day after the application of the products, germination had decreased compared to the control, especially in the treatments with gastoxin, PET container, and cinnamon bark. Despite this reduction, in all cases, the germination percentage remained above $80 \%$, which is the minimum standard required for commercialization (Brasil, 2013).

The lowering in toxicity values, when early and late storage phases are compared, may be the result of the packing used (Kraft paper), which is permeable and may have permitted the escape of gases that were initially toxic to the seeds. This outcome is very relevant, once it evidenced that the alternative treatments tested in this study had almost no detrimental effects on the physiologic quality of bean seeds. Many authors have reported the use of powders, extracts, and oils from plants with insecticide properties for controlling weevils, once they inhibit the action of bruchids without damaging the seeds (Mateus et al., 2017; Girão Filho et al., 2014; Borsonaro et al., 2013; Silva et al., 2013a; Silva et al., 2013b; Queiroga et al., 2012; Garcia et al., 2007).

Regarding the emergence speed index and mean emergence time, no significant difference was observed among the treatments. Such a result attests that the alternative treatments applied were not harmful to the vigor of the seeds.

The PET-container treatment scored the highest weight of one thousand seeds, from the $25^{\text {th }}$ day until the end of the storage period (Table 2). The reason probably has to do with the lack of permeability of the material, which prevents seeds from losing water to the environment. The same did not occur to the other treatments, which had been packed in kraft paper bags (Figure 1). In general, the weight of one thousand seeds tended to reduce as the storage time progressed. This behavior is more related to a variation in the moisture content of the seeds (Figure 1) than to the presence of insects in the treatments, once the highest incidence of damaged seeds (Table 3) did not correspond to the lowest value of the feature weight of one thousand seeds (Table 2).
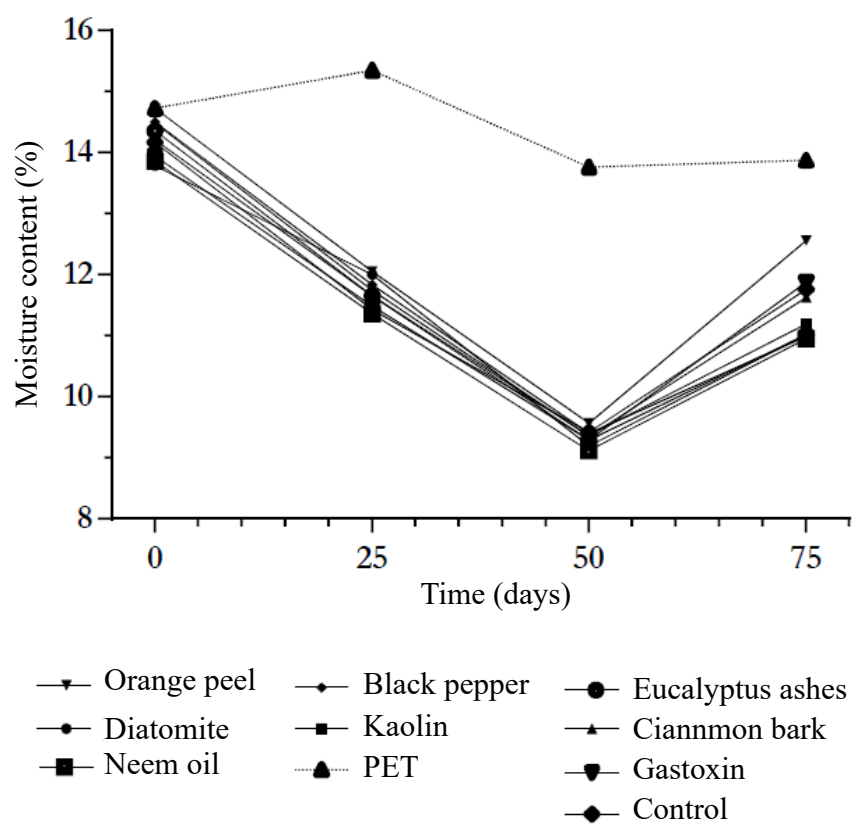

Figure 1. Moisture content (\%) of Phaseolus vulgaris seeds submitted to different products after $0,25,50$, and 75 days of storage.

Table 1. Germination (\%) of P. vulgaris seeds submitted to different treatments and stored for $0,25,50$, and 75 days.

\begin{tabular}{lcllc}
\hline \multicolumn{1}{c}{ TREAT. } & Day 0 & 25 days & 50 days & 75 days \\
\hline T1- Diatomaceous earth & $93.25 \mathrm{Ba}$ & $94.00 \mathrm{Aa}$ & $92.50 \mathrm{Aa}$ & $89.50 \mathrm{BCa}$ \\
T2- Kaolin & $93.25 \mathrm{Ba}$ & $97.00 \mathrm{Aa}$ & $93.50 \mathrm{Aa}$ & $94.50 \mathrm{ABa}$ \\
T3- Cinnamon bark & $100.00 \mathrm{Aa}$ & $95.00 \mathrm{Aab}$ & $94.50 \mathrm{Ab}$ & $88.00 \mathrm{BCDc}$ \\
T4- Orange peel & $83.50 \mathrm{Cc}$ & $97.50 \mathrm{Aa}$ & $96.00 \mathrm{Aa}$ & $90.00 \mathrm{BCb}$ \\
T5- Black pepper & $75.00 \mathrm{Db}$ & $97.00 \mathrm{Aa}$ & $96.50 \mathrm{Aa}$ & $97.25 \mathrm{Aa}$ \\
T6- Eucalyptus ashes & $97.00 \mathrm{Aba}$ & $92.00 \mathrm{Aa}$ & $96.50 \mathrm{Aa}$ & $97.25 \mathrm{Aa}$ \\
T7- Neem oil & $78.50 \mathrm{CDb}$ & $95.25 \mathrm{Aa}$ & $95.00 \mathrm{Aa}$ & $90.00 \mathrm{BCa}$ \\
T8- PET container & $98.50 \mathrm{Aba}$ & $95.50 \mathrm{Aa}$ & $94.50 \mathrm{Aa}$ & $84.50 \mathrm{CDb}$ \\
T9- Gastoxin & $92.50 \mathrm{Ba}$ & $97.00 \mathrm{Aa}$ & $93.00 \mathrm{Aa}$ & $82.25 \mathrm{Db}$ \\
T10- Control & $95.00 \mathrm{ABab}$ & $98.00 \mathrm{Aa}$ & $94.50 \mathrm{Aab}$ & $92.50 \mathrm{ABb}$ \\
\hline CV & & & $3.15 \%$ & \\
\hline
\end{tabular}

Means followed by the same uppercase letter, in the columns, and lowercase letter, in the rows, do not differ statistically at a 0.05 probability level, according to the Tukey's test. CV values indicate the coefficient of variation (\%). 
Table 2. Weight of one thousand seeds of $P$. vulgaris submitted to different treatments and stored for $0,25,50$, and 75 days.

\begin{tabular}{llllc}
\hline \multicolumn{1}{c}{ TREAT. } & Day 0 & 25 days & 50 days & 75 days \\
\hline T1- Diatomaceous earth & $205.68 \mathrm{Aa}$ & $197.77 \mathrm{Bb}$ & $191.76 \mathrm{Bc}$ & $195.89 \mathrm{Bbc}$ \\
T2- Kaolin & $201.91 \mathrm{Aa}$ & $196.03 \mathrm{Bb}$ & $189.74 \mathrm{Bc}$ & $193.91 \mathrm{Bbc}$ \\
T3- Cinnamon bark & $204.96 \mathrm{Aa}$ & $199.26 \mathrm{Bb}$ & $191.56 \mathrm{Bc}$ & $193.17 \mathrm{Bc}$ \\
T4- Orange peel & $203.23 \mathrm{Aa}$ & $198.50 \mathrm{Bab}$ & $192.83 \mathrm{Bc}$ & $197.01 \mathrm{Bbc}$ \\
T5- Black pepper & $204.86 \mathrm{Aa}$ & $200.68 \mathrm{Bab}$ & $192.34 \mathrm{Bc}$ & $197.93 \mathrm{Bb}$ \\
T6- Eucalyptus ashes & $201.85 \mathrm{Aa}$ & $199.30 \mathrm{Ba}$ & $189.66 \mathrm{Bb}$ & $197.08 \mathrm{Ba}$ \\
T7- Neem oil & $204.95 \mathrm{Aa}$ & $199.77 \mathrm{Bb}$ & $191.82 \mathrm{Bc}$ & $197.03 \mathrm{Bb}$ \\
T8- PET container & $201.93 \mathrm{Ab}$ & $208.85 \mathrm{Aa}$ & $201.15 \mathrm{Ab}$ & $204.55 \mathrm{Aab}$ \\
T9- Gastoxin & $202.78 \mathrm{Aa}$ & $198.16 \mathrm{Bab}$ & $190.51 \mathrm{Bc}$ & $194.93 \mathrm{Bbc}$ \\
T10- Control & $202.41 \mathrm{Aa}$ & $198.14 \mathrm{Bab}$ & $190.14 \mathrm{Bc}$ & $196.21 \mathrm{Bb}$ \\
\hline \multicolumn{1}{c}{ CV } & & & $2.02 \%$ \\
\hline
\end{tabular}

Means followed by the same uppercase letter, in the columns, and lowercase letter, in the rows, do not differ statistically at a 0.05 probability level, according to the Tukey's test.

Table 3. P. vulgaris seeds infested (damaged by insects, \%), submitted to different treatments and stored for $0,25,50$, and 75 days.

\begin{tabular}{lcccc}
\hline \multicolumn{1}{c}{ TREAT. } & Day 0 & 25 days & 50 days & 75 days \\
\hline T1- Diatomaceous earth & $0.00 \mathrm{Aa}$ & $2.50 \mathrm{Aa}$ & $0.00 \mathrm{Aa}$ & $1.00 \mathrm{Aa}$ \\
T2- Kaolin & $0.00 \mathrm{Aa}$ & $4.50 \mathrm{Aa}$ & $6.50 \mathrm{ABa}$ & $1.50 \mathrm{Aa}$ \\
T3- Cinnamon bark & $0.00 \mathrm{Aa}$ & $4.50 \mathrm{Aa}$ & $14.50 \mathrm{ABCa}$ & $10.50 \mathrm{Aa}$ \\
T4- Orange peel & $0.00 \mathrm{Ac}$ & $2.50 \mathrm{Ac}$ & $24.00 \mathrm{BCb}$ & $47.50 \mathrm{Ba}$ \\
T5- Black pepper & $0.00 \mathrm{Aa}$ & $6.50 \mathrm{Aa}$ & $0.50 \mathrm{Aa}$ & $3.50 \mathrm{Aa}$ \\
T6- Eucalyptus ashes & $0.00 \mathrm{Aa}$ & $4.00 \mathrm{Aa}$ & $2.50 \mathrm{ABa}$ & $1.00 \mathrm{Aa}$ \\
T7- Neem oil & $0.00 \mathrm{Aa}$ & $6.50 \mathrm{Aa}$ & $0.50 \mathrm{Aa}$ & $0.50 \mathrm{Aa}$ \\
T8- PET container & $0.00 \mathrm{Aa}$ & $1.00 \mathrm{Aa}$ & $4.50 \mathrm{ABa}$ & $6.50 \mathrm{Aa}$ \\
T9- Gastoxin & $0.00 \mathrm{Ab}$ & $6.00 \mathrm{Ab}$ & $6.00 \mathrm{ABb}$ & $41.50 \mathrm{Ba}$ \\
T10- Control & $0.00 \mathrm{Ab}$ & $6.00 \mathrm{Ab}$ & $33.50 \mathrm{Ca}$ & $33.50 \mathrm{Ba}$ \\
\hline CV & & & 95.92 & \\
\hline
\end{tabular}

Means followed by the same uppercase letter, in the columns, and lowercase letter, in the rows, do not differ statistically at a 0.05 probability level, according to the Tukey's test.

Still regarding the variable weight of one thousand seeds, the fact that most of the A. obtectus lifecycle occurs inside the seed might have contributed to the absence of significant differences among the treatments (except for the PET containers). Thus, even if the insect feeds on the seed, any alteration in its mass may go unnoticed due to larva developing within it. This result corroborates those of Lima et al. (2014), who did not observe a decrease in the weight of one thousand seeds of black-eyed peas infested with different weevil densities.

A higher weevil infestation in seeds was remarked during storage, after 50 days (Table 3). Among the treatments applied, the diatomaceous earth, kaolin, cinnamon bark, black pepper, eucalyptus ashes, neem oil, and PET container were worth noticing. They presented a lower amount of infested seeds, ranging from 0 to $10.5 \%$, in comparison with the treatments with orange peel, gastoxin, and the control $(47.5,41.5$, and
$33.5 \%$, respectively, by the $75^{\text {th }}$ day). Black pepper (Garcia et al., 2007) and orange peel (França et al., 2012) had been referred to as efficient methods to control $Z$. subfasciatus. However, in the present work, a high infestation of $A$. obtectus occurred, despite the use of orange peel, which proved to be inefficient in handling this pest.

Mikami etal.(2010) assessed the effect of the diatomaceous earth and kaolin for the control of Z. subfasciatus. They found that the diatomaceous earth at the dosage of $1 \mathrm{~g}^{\mathrm{kg}} \mathrm{kg}^{-1}$ of seed caused the death of all female and male insects on the third and fourth days, respectively; whereas the kaolin extinguished all females and 92 to $96 \%$ of males up from the fourth day.

Figure 2 depicts the repellency index right after the application of the treatments and six months later. It is possible to notice that the treatments with kaolin and neem oil acted as a repellent at the beginning of the analysis, but lost their effectiveness by the end of six months. On the other hand, 


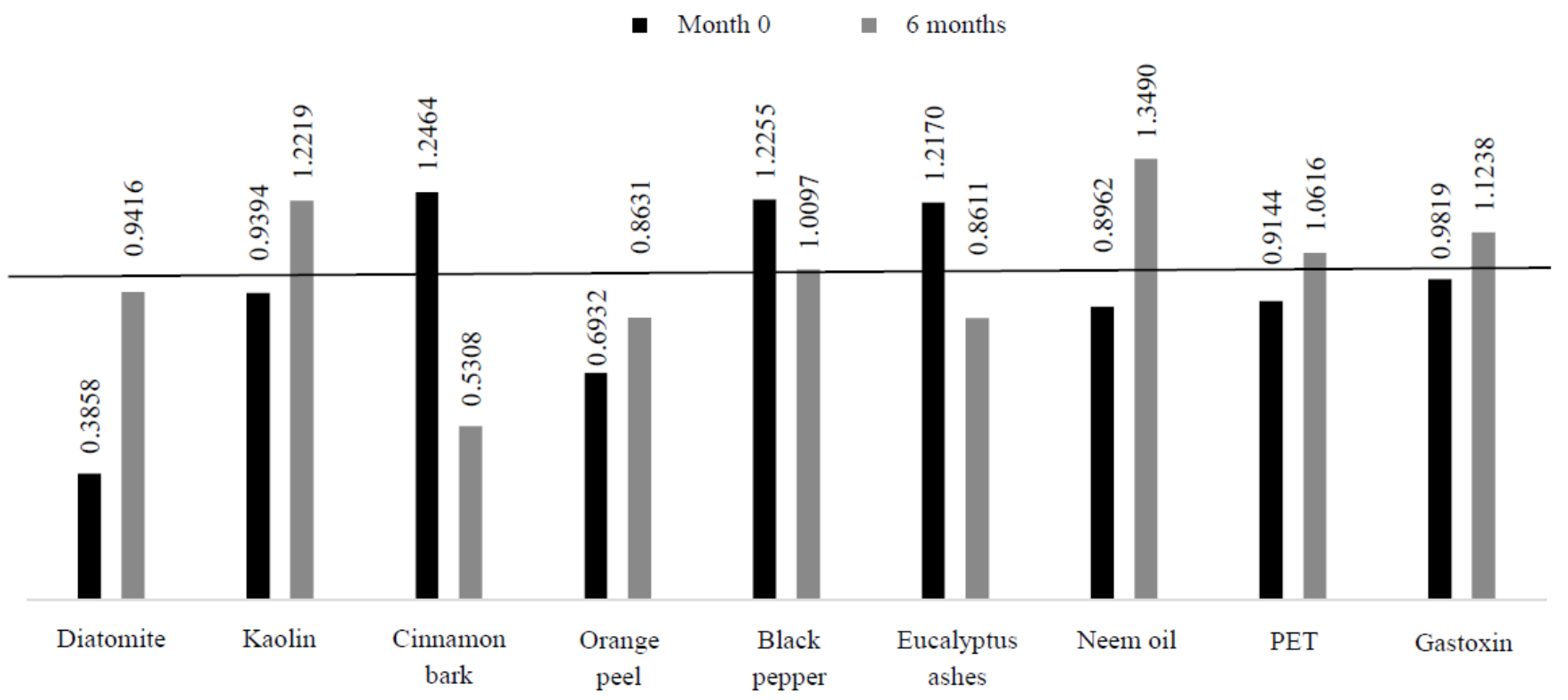

Repellency Index $=$ RI $>1$ : attractive; IR $<1$ : repellent; $I R=1$ : neutral (full line)

Figure 2. Repellency index to A. obtectus in seeds of $P$. vulgaris submitted to different treatments, initially and after six months of storage.

cinnamon bark and eucalyptus ashes did not have a repellent effect at first but became more active over time. Last, orange peel and diatomaceous earth repelled the insects, both at the initial moments and by the end of the storage period.

Even though kaolin and neem oil lost their effectiveness over six months of storage, the initial repellency was fundamental to diminish the infestation by A. obtectus. This insect can perform cross-infestation, starting from the field or the warehouse (Jiménez et al., 2017). Thus, the capacity of such products in repelling insects that contaminate seeds since cultivation can contribute to lower their population in storage places.

Oliveira and Vendramim (1999) also reported the repellency to $Z$. subfsciatus when ground cinnamon leaves were used. Procópio et al. (2003), in their turn, tested the repellency and preference index of vegetable powders in $A$. obtectus and $Z$. subfasciatus. They verified that, among the treatments assessed, only the powder of eucalyptus leaves repelled the insects.

\section{Conclusions}

According to the results, the treatments with diatomaceous earth, kaolin, black pepper, cinnamon bark, eucalyptus ashes, neem oil, and PET container are efficient in reducing the infestation by weevils, without compromising the physiological quality of the seeds.
As for the repellency test, the treatments with kaolin and neem oil are repellent at the beginning of the storage but lose effectiveness by the end of it. Products made from cinnamon bark, and those made from eucalyptus ashes do not have a repellent effect at first but become more active over time. Products made from orange peel and those from diatomaceous earth repel the insects, both at the beginning and at the end of the storage. Last, black pepper is not effective in repelling the insects at the initial moment, and its condition remains neutral until the end of the storage time.

\section{References}

BORSONARO, M.T.; SENÔ, K.C.A.; IAMAGUTI, P.S.; NEVES, M.C.T.; SILVA, P.T. Extrato aquoso de folhas de Azadirachta indica A. Juss no controle de Sitophilus zeamais Mots. (Coleoptera: Curculionidae) em milho armazenado. Nucleus, v.10, n.1, p.161-167, 2013. http://www.nucleus.feituverava.com. br/index.php/nucleus/article/view/858/1126

BRASIL. Ministério da Agricultura Pecuária e Abastecimento. Regras para análise de sementes. Ministério da Agricultura, Pecuária e Abastecimento. Secretaria de Defesa Agropecuária. Brasília: MAPA/ACS, 2009. 395p.

BRASIL. Instrução Normativa $n^{\circ}$ 45, de 17 de setembro de 2013. Diário Oficial da União, Ministério da Agricultura, Pecuária e Abastecimento, Brasília, DF, 20 set. 2013, Seção I, anexo XI. p.16. http://apasem.com.br/site/wp-content/uploads/padroesin0452013.pdf 
CAMPOS, A.C.T.; RADUNZ, L.L.; RADÜNZ, A.L.; MOSSI, A.J.; DIONELLO, R.G.; ECKER, S.L. Atividade repelente e inseticida do óleo essencial de carqueja doce sobre o caruncho do feijão. Revista Brasileira de Engenharia Agrícola e Ambiental, v.18, n.8, p.861-865, 2014. http://www.lume.ufrgs.br/bitstream/ handle/10183/112133/000932643.pdf?sequence=1

CRISTO, T.; BISCHOFF, T.Z.; SILOCHI, R.M.Q.; SCHOENINGER, V.; COELHO, S.R.M. Aspectos relacionados a qualidade do feijão comum. Journal of Agronomic Sciences, v.3, n.especial, p.39-46, 2014. http://www.dca.uem.br/V3NE/04.pdf

DAMIANI, C.B.; BOFF, M.I.C.; FRANCO, C.R.; COELHO, C.M.M.; SOUZA, C.A. Comportamento e aspectos biológicos de Acanthoscelides obtectus (Coleoptera: Bruchidae) em cultivares crioulas de feijão Phaseolus vulgaris. Revista de la Facultad de Agronomía, v.113, n.1, p.9-17, 2014. http://www.agro.unlp.edu.ar/ revista/index.php/revagro/article/view/13

FRANÇA, S.M.; OLIVEIRA, J.V.; ESTEVES FILHO, A.B.; OLIVEIRA, C.M. Toxicity and repellency of essencial oils to Zabrotes subfasciatus (Boheman) (Coleoptera, Chrysomelidae, Bruchinae) in Phaseolus vulgaris L. Acta Amazônica, v.42, n.3, p.381-386, 2012. http://www.scielo.br/pdf/aa/v42n3/a10v42n3.pdf

GALLO, D.; NAKANO, O.; SILVEIRA NETO, S.; CARVALHO, R.P.L.; BATISTA, G.C.; BERTI FILHO, E.; PARRA, J.R.P.; ZUCCHI, R.A.; ALVES, S.B.; VENDRAMIM, J.D.; MARCHINI, L.C.; LOPES, J.R.S.; OMOTO, C. Entomologia agrícola. Piracicaba: FEALQ, 2002. 920p.

GARCIA, J.; VELOSO, V.R.S.; DUARTE, J.B.; KAMADA, T. Eficiência de produtos alternativos no controle Zabrotes subfasciatus, e seus efeitos sobre a qualidade das sementes de Phaseolus vulgaris. Pesquisa Agropecuária Tropical (Agricultural Research in the Tropics), v.30, n.2, p.39-42, 2007. https://www.revistas.ufg.br/pat/ article/view/2765/2769

GIRÃO FILHO, J.E.; ALCÂNTARA NETO, F.; PÁDUA, L.E.M.; PESSOA, E.F. Repelência e atividade inseticida de pós vegetais sobre Zabrotes subfasciatus Boheman em feijão-fava armazenado. Revista Brasileira de Plantas Medicinais, v.16, n.3, p.499-504, 2014. http://www.scielo.br/scielo.php?pid=S1516$05722014000300004 \&$ script $=$ sci_arttext

JIMÉNEZ, J.C.; LA FUENTE, M.; ORDÁS, B.; DOMÍNGUEZ, L.E.G.; MALVAR, R.A. Resistance categories to Acanthoscelides obtectus (Coleoptera: Bruchidae) in terapy bean (Phaseolus acutifolius), new sources of resistance for dry bean (Phaseolus vulgaris) breeding. Crop Protection, v.98, p.255-266, 2017. http:// www.sciencedirect.com/science/article/pii/S0261219417301151

LIMA, J.D.; ALMEIDA, C.C.; DANTAS, V.A.V.; SIBA, B.M.; MORAES, W.S. Efeito da temperatura e do substrato na germinação de sementes de Caesalpinia ferrea Mart. ex Tul. (Leguminosae, Caesalpinoideae). Revista Árvore, v.30, p.513-518, 2006. http:// www.scielo.br/pdf/rarv/v30n4/31671.pdf

LIMA, J.M.E.; FAGUNDES, G.S.; SMIDERLE, O.J. Qualidade fisiológica de sementes de Feijão-Caupi tratadas com terra diatomácea e infestadas por carunchos. Revista em Agronegócio e Meio Ambiente, v.7, n.3, p.733-746, 2014. http://periodicos. unicesumar.edu.br/index.php/rama/article/view/3029/2409
LIMA-MENDONÇA, A.; BROGLIO, S.M.F.; ARAÚJO, A.M.N.; LOPES, D.O.P.; DIAS-PINI, N.S. Efeito de pós vegetais sobre Sitophilus zeamais (Mots., 1855) (Coleoptera: Curculionidae). Arquivos do Instituto Biológico, v.80, n.1, p.91-97, 2013. http:// www.scielo.br/pdf/aib/v80n1/a13v80n1.pdf

LIN, H.; KOGAN, M.; FISCHER, D. Induced resistance in soybean to the Mexican bean beetle (Coleoptera: Coccinellidae): comparisons of inducing factors. Environmental Entomology, v.19, p.1852-1857, 1990. https://academic.oup.com/ee/article-abstract/19/6/1852/24804 73?redirectedFrom=fulltext

MATEUS, A.E.; AZEVEDO, F.R.; ALVES, A.C.L.; FEITOSA, J.V. Potencial da Moringa oleifera como inseticida no controle de adultos de Sitophilus zeamais (Coleoptera: Curculionidae) em grãos de milho armazenados. Acta Iguazu, v.16, n.2, p.112-122, 2017. http://erevista.unioeste.br/index.php/actaiguazu/article/view/17538/11687

MELO, B.A.; MOLINA-RUGAMA, A.J.; LEITE, D.T.; GODOY, M.S.; ARAUJO, E.L. Bioatividade de pós de espécies vegetais sobre a reprodução de Callosobruchus maculatus (FABR. 1775) Coleoptera: Bruchidae). Bioscience Journal, v.30, n.3, p.346-353, 2014. http://www. seer.ufu.br/index.php/biosciencejournal/article/view/18187/14546

MIKAMI, A.Y.; PISSINATI, A.; FAGOTTI, D.; JÚNIOR, A.O.M.; VENTURA, M.U. Control of the Mexican bean weevil Zabrotes subfasciatus with kaolin. Ciencia Rural, v.40, n.7, p.1497-1501, 2010. http://www.scielo.br/pdf/cr/v40n7/a640cr1737.pdf

OLIVEIRA, J.V.; VENDRAMIM, J.D. Repelência de óleos essenciais e pós vegetais sobre adultos de Zabrotes subfasciatus (Boh.)(Coleoptera: Bruchidae) em sementes de feijoeiro. Anais da Sociedade Entomológica do Brasil, v.28, n.3, p.549-555, 1999. https://scholar.google.com.br/scholar?q=Repel\%C3\%AAn$\mathrm{cia}+\mathrm{de}+\% \mathrm{C} 3 \% 931$ eos + Essenciais $+\mathrm{e}+\mathrm{P} \% \mathrm{C} 3 \% \mathrm{~B} 3 \mathrm{~s}+$ Vegetais + sobre + Adultos + de + Zabrotes + subfasciatus $+\% 28$ Boh. $\% 29+\% 28 \mathrm{Co}-$ leoptera $\% 3 \mathrm{~A}+$ Bruchidae $\% 29+\mathrm{em}+$ Sementes + de + Feijoeiro\&bt$\mathrm{nG}=\& \mathrm{hl}=\mathrm{pt}-\mathrm{BR} \&$ as_sdt $=0 \% 2 \mathrm{C} 5$

OLIVEIRA, M.R.C.; CORREA, A.S.; SOUZA, G.A.; GUEDES, R.N.C.; OLIVEIRA, L.O. Mesoamerican origin and pre and PostColumbian expansions of the ranges of Acanthoscelides obtectus Say, a cosmopolitan insect pest of the common bean. PLoS One, v.8, n.7, p.1-12, 2013. http://dx.doi.org/10.1371/journal.pone.0070039

OOTANI, M.A.; AGUIAR, R.W.; RAMOS, A.C.C.; BRITO, D.R.; SILVA,J.B.; CAJAZEIRA,J.P.Use of essentialoils in agriculture.Journal of Biotechnology and Biodiversity, v.4, n.2, p.162-174, 2013. https:// www.researchgate.net/profile/Marcio_Ootani/publication/296484491_ Journal_of_Biotechnology_and_Biodiversity_Use_of_Essential_Oils_ in_Agriculture/links/56d5b97808 9 aee73df6c0500a.pdf

PROCÓPIO, S.O.; VENDRAMIM, J.D.; JUNIOR, J.I.R.; SANTOS, J.B. Efeito de pós vegetais sobre Acanthoscelides obtectus (SAY) e Zabrotes subfasciatus (BOH.) (COLEOPTERA: BRUCHIDAE). Ceres, v.50, n.289, p.395-405, 2003. http://www. ceres.ufv.br/ojs/index.php/ceres/article/view/2877/742 
QUEIROGA, M.F.C.; GOMES, J.P.; ALMEIDA, F.A.C.; PESSOA, E.B.; ALVES, N.M.C. Aplicação de óleo no controle de Zabrotes subfasciatus e na germinação de Phaseolus vulgaris. Revista Brasileira de Engenharia Agricola e Ambiental-Agriambi, v.16, n.7, p.777-783, 2012. https://scholar.google.com.br/scholar?hl=pt-BR\& $\mathrm{q}=$ Aplica $\% \mathrm{C} 3 \% \mathrm{~A} 7 \% \mathrm{C} 3 \% \mathrm{~A} 3 \mathrm{o}+\mathrm{de}+\% \mathrm{C} 3 \% \mathrm{~B} 31 \mathrm{leo}+$ no + controle + de + Zabrotes + subfasciatus + e + na + germina $\% \mathrm{C} 3 \% \mathrm{~A} 7 \% \mathrm{C} 3 \% \mathrm{~A} 3 \mathrm{o}+\mathrm{de}+\mathrm{Ph}$ aseolus + vulgaris $\& b \operatorname{tnG}=\& 1 \mathrm{r}=$

SILVA, D.F.G.; AHRENS, D.C.; PAIXÃO, M.F.; SOKARA NETO, F.; ROMEL, C.C.; COMIRAN, F.; NAZARENO, N.R.X.; COELHO, C.J. Tratamento de milho em grão e espiga com pós inertes no controle do gorgulho do milho Sitophilus zeamais. Revista Brasileira de Agroecologia. v.7, n.3, p.143-151, 2012. http:// orgprints.org/22796/1/10992-54125-1-PB.pdf

SILVA, F.A.S.; AZEVEDO, C.A.V. The Assistat Software Version 7.7 and its use in the analysis of experimental data. African Journal of Agricultural Research, v.11, n.39, p.3733-3740, 2016. http://www.academicjournals.org/journal/AJAR/article-full-textpdf/5E8596460818
SILVA, F.S.; PORTO, A.G.; PASCUALI, L.C.; SILVA, F.D. Viabilidade do armazenamento de sementes em diferentes embalagens para pequenas propriedades rurais. Revista de Ciências Agro-Ambientais, v.8, n.1, p.45-56, 2010. http://www.unemat.br/ revistas/rcaa/docs/vol8/5_artigo_v8.pdf

SILVA, J.F.; MELO, B.A.; CORDEIRO, M.F.R.; LEITE, D.T.; BULHÕES, A.A. Resposta de Sitophilus zeamais Motschulsky 1885 (Coleoptera: Curculionidae) frente ao extrato de Capsicum annuum L. Revista Verde de Agroecologia e Desenvolvimento Sustentável, v.8, n.2, p.05-08, 2013a. http://gvaa.org.br/revista/index.php/ RVADS/article/view/2160/1652

SILVA, J.F.; MELO, B.A.; PESSOA, E.B.; FIGUEIREDO NETO, A.; LEITE, D.T. Extratos vegetais para o controle de caruncho-do-feijão Zabrotes subfaciatus (Boheman 1833) (Coleoptera:Bruchidae). Revista Verde de Agroecologia e Desenvolvimento Sustentável, v.8, n.3, p.01-05, 2013b. http://gvaa.com.br/revista/index.php/RVADS/ article/view/2240/1706 